Prof. Alex. Agassiz must have strangely misread that paragraph in my lecture in which I refer to the two deepest soundings of the Tuscarora if he supposes that I intended to cast any doubt upon their trustworthiness as indicating "depths considerably exceeding 4,000 fathoms." In the Official Report, now before me, these two soundings are thus recorded :-

"No. $15: 4,643$ fathoms. No specimen (of bottom). Wire broke. Bottom not reached.

"No. 33: 4,655 fathoms. No specimen. Wire broke."

As there is no mention in the second case of the wire having broken in reeling-in (which is stated in several other cases), and as the length of wire run out corresponded almost exactly with that run out in the first, it was not unnatural that I should suppose that the wire broke by its own weight without reaching bottom. But I expressly cited these two soundings, incomplete though they were (no specimen of bottom having been brought up), as evidence in support of my case that those "gigantic pitholes," in which extraordinary depths have been encountered, occur in regions of great Volcanic activity.

$$
\text { 56, Regent's Park Road, William B. CARPenter }
$$$$
\text { N.W., April } 27
$$

\section{Seeing by Electricity}

WITr respect to the letter of Messrs. Ayrton and Perry (NATURE, vol. xxi. p. 589), in which they propose to utilise for this purpose Dr. Kerr's discovery of the rotatipn of the plane of polarisation of light reflected from the pole of a magnet, will you allow me to give you some details of a repetition of Dr. Kerr's experiment which I made a year or two ago.

I used an electromagnet consisting of an iron bar 2 feet 4 inches long and $2 \frac{1}{4}$ inches diameter, surrounded by 70 lbs. of wire, and excited by ten Grove cells.

The total double rotation produced, not by slightly altering the resistance, but by reversing the current, was never more than $26^{\prime}$ (twenty-six minutes of arc).

To see this at all with a very delicate Jellett analyser, it was necessary for the observer to increase the sensitiveness of his eye by sitting in total darkness for some ten minutes before each observation.

Your readers can judge what chance of obtaining visible changes of illumination there would be with "little "magnets and mere variations in a current not powerful enough to fuse a selenium resistance.

32, Elvaston Place, Queen's Gate, S. W., April 22

\section{Ophiolepis mirabilis}

THE statement concerning Prof. Martin Duncan's Ophiolepis mirabilis contained in the review of Prof. Lyman's account of the Challenger Ophiurans was not intended to represent an expression of opinion of the Reviewer upon the matter, but simply the conclusions of Prof. Lyman as expressed in the memoir under review. The matter was not cited as a question of mistake, but of difference of opinion between two experts. Prof. Lyman enters, in the memoir referred to, at some length into his reasons for considering Prof. Duncan's species, as described, to be a true Ophiopholis. This latter genus Prof. Lyman thinks quite remote from Ophiolepis, in spite of the evidence adduced by Prof. Duncan. I am sorry that I did not make it clear that I was citing Prof. Lyman's opinion and not expressing any judgment of my own. The REVIEWER IN QUESTION

\section{The Ômori Shell-Heaps}

DESIRING as much as possible to save space and avoid rhetoric, I shall be content to reply to the pith of Prof. Morse's amusing diatribe contained in NATURE, vol. xxi. p. 501 , principally by citing extracts from a recent paper on Prehistoric Remains in Japan, read by Prof. Milne before the Asiatic Society of Japan, and printed, together with a report of the discussion it gave rise to, in their.Transactions, published in February last, which I received about a fortnight ago.

The main object of my note in NATURE, vol. xxi. p. 350, was to show that the antiquity claimed by Prof. Morse for the Ômori mounds was not warranted by the facts. In this view I am supported by Prof. Milne, Dr. Faulds, and Mr. Aston, whose united authority I venture to prefer to that of the Salem zoologist.

Prof. Milne examined a number of shell-mounds in various parts of Japan, both in Yezo, where the Aino race still flourishes, and in the main island, including the Ômori heaps, but he does not mention having met with any human remains in any of them. Adverting to Prof. Morse's conclusions from his examination of the Jmori shells, which may be briefly presented thus:-

That changes have taken place in the relative abundance, size, and proportions of certain species and in the extinction of certain species,

Prof. Milne quotes from the Memoir : " The modification in the relative size, \&c., is profound, and seems to indicate" either a shorter period of species-variation than is commonly admitted, "or else that the deposits presenting these peculiarities have a much higher antiquity than had before been accorded them." Prof. Milne (but then he is merely a "Briton in Japan," and $q u \hat{a}$ such disposed, doubtless, in the eyes of Prof. Morse, to sneer at everything Japanese, shell-mounds included) is inclined to think these modifications "in great measure due to the great changes which have been taking place in Yedo Bay during recent times." The italics are Prof. Milne's. ".. The bay is rapidly silting up. . . during the last 800 years large cities have sprung up round its shores, all of which have added something to destroy the purity of its shallower waters. All these causes combined are and have been making changes in physical conditions, and with them we should naturally expect a rapid change in the faunæ which are dependent on them." Further on a map is given showing the ancient coast lines at and near Yedo, and proving the magnitude and rapidity of the various successive encroachments of the shores upon the waters of the bay.

Again, "The conclusion to which I am led with regard to the shell-heaps is that they are of Aino origin ... the positions which these shell-heaps occupy are on spots which we know ... were once tenanted by Ainos, and even down to the end of the twelfth century Ainos were living in Nipon." By Nipon is meant, I presume, the main island. I may add that I have often heard from Japanese of Aino colonies still existing in the northeastern districts of the main island, but not distinguishable by language, or customs, or otherwise than physically from their Japanese neighbours. The average advancement of the land at and near Yedo, Prof. Milne states as varying from 38 feet to 2 feet per annum, which would account for the present distance of the Ômori heap from the shore being attained in from something under roo to something over I, 000 years. Mr. Aston, in the course of the discussion which followed the reading of Prof. Milne's paper-I quote from the report in the Transactions"was glad to observe a tendency to diminish the antiquity which had been earlier assigned to these remains (from Ômori) by some of the writers on the subject. Civilisation in Japan is a product of much more recent growth than in Europe, and we do not require to go so far back in order to meet with tokens of a primitive degree of advancement." Mr. Aston then showed that in the middle of the eighth century a large portion of the main island was exclusively Aino. Dr. Faulds assigned " 600 years as the probable antiquity of the Ômori heap," and Prof. Milne in reply said that the rise of land variously evidenced round Yedo Bay, " taken in conjunction with the vast deposits of silt which are brought down by the various large rivers which flow into the bay, would make the changes in coast-line exceed. ingly rapid."

With regard to the pottery of the Ômori heaps, Prof. Milne says: "The designs are in very many instances similar to the designs which are carved by the Ainos of the present day." On this point Dr. Faulds's testimony is more emphatic. "The 'mat' impressions figured by "Prof. Morse in Plate V. Fig. I, are to be found repeated in the most recent pottery;" the types of pottery in the shell-heaps did not seem " to be separated by any one well-marked character from contemporary pottery of a low grade. The shell-heaps scattered along the old and recent coasts of Yedo Bay presented in their fragments of pottery a series of modifications leading up to recent times, and some of the heaps may be seen in actual process of accumulation." Further, Mr. Ninagawa of the Tokio Museum, the principal authority on the subject of Japanese pottery, decides that the "remains . . . cannot be older than $\mathrm{I}$, 000 years." Dr. Faulds showed some coarse pottery of the day not dissimilar to that of the shell-heaps, and was not even prepared "to accept finally the belief that the Ainos were the founders of these heaps."

From personal investigation of many remains of shell-heaps on the coast-line and inland between Yedo and Yokosuka, I can corroborate Dr. Faulds's statement. I do, however, believe that the heaps at Ômori were the handiwork of Ainos, very 